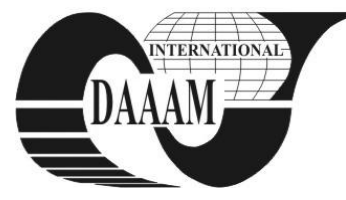

Annals of DAAAM for 2011 \& Proceedings of the 22nd International DAAAM Symposium, Volume 22, No. 1, ISSN 1726-9679 ISBN 978-3-901509-83-4, Editor B. Katalinic, Published by DAAAM International, Vienna, Austria, EU, 2011 Make Harmony between Technology and Nature, and Your Mind will Fly Free as a Bird Annals \& Proceedings of DAAAM International 2011

\title{
NUMERICAL MODELING OF MICRO-CRACK PROPAGATION IN COMPOSITES
}

\author{
MAJER, Z[denek]
}

\begin{abstract}
The main objective of this paper is the numerical investigation of fracture behaviour in polymeric particulate composite with rigid particles. This article is focused on estimation of next micro-crack propagation in nonlinear matrix. The composite is modelled as a three-phase continuum and using finite element method is solved. The interaction of micro-crack and particles covered by the interphase is analyzed.
\end{abstract}

Key words: particulate composite, nonlinear matrix, FEM

\section{INTRODUCTION}

The polymeric particulate composite especially with rigid particles (i. e. $\mathrm{H}_{2} \mathrm{MgO}_{2}$ or $\mathrm{Mg}(\mathrm{OH})_{2}$ ) are considerable influence in many engineering applications. Due to possibility of mechanical properties modifying composites are in the forefront of research. The polypropylene composites filled by rigid particles are one of the most widely used materials with a thermoplastic matrix. The change of properties of the matrix and rigid particles (size, shape, material properties) can have a significant effect on the global behavior of the composite. The uses of rigid particles cause mainly increase of composite Young's modulus. On other side, the addition of rigid particles to a soft polymer matrix has an embrittling effect on the composite. Both these effects go against each other and it is necessary estimated both. The influence of matrix material properties change on global composite Young's modulus was studied (Majer, 2010). This paper on influence of matrix material properties change on next micro-crack propagation is focused.

The model of particulate composite is created with respect some general terms (Zuiderduin et al., 2003): (I) aspect ratio of particles must be close to unity to avoid high stress concentration, (II) particles should be of small size (less than $5 \mu \mathrm{m}$ ), (III) particles must debond prior to the yield strain of the matrix polymer in order to change the stress state of the matrix material and (IV) particles must be dispersed homogeneously in the matrix polymer. The composite with perfect homogeneous distribution of the particles in the matrix is considered (Jančár et al., 1991). The production of the composite can lead to formation of particles clusters (Kiss et al., 2007). The influence of particles random distribution in matrix on the global behavior of the composite was studied too (Prod'Homme et al., 2008).

Interaction between particles and matrix during production can lead to creation third phase, generally called interphase. According to experiments observation the interphase may causes change the composite global behavior. It is very difficult to obtain directly relevant information about thickness and material properties of interphase that they must be determined indirectly from a composite property (Pukánszky, 2005). The value of interphase thickness depends on the method of determination. In the literature the thickness estimation varies from $0.012 \mu \mathrm{m}$ to $0.16 \mu \mathrm{m}$. In the paper (Moczó et al., 2002) the thickness of the studied interphases was estimated as

\begin{tabular}{|c|c|c|c|c|c|c|c|c|c|c|}
\hline Material & S & F2 & F4 & F6 & S2 & S4 & S6 & N2 & N4 & N6 \\
\hline Filler & - & \multicolumn{3}{|c|}{$\begin{array}{c}\text { KISUMA 5AU } \\
\text { company modified }\end{array}$} & \multicolumn{3}{|c|}{$\begin{array}{c}\text { MAGNIFIN } 10 \\
\text { modified }\end{array}$} & \multicolumn{3}{|c|}{$\begin{array}{c}\text { MAGNIFIN H } 10 \\
\text { unmodified }\end{array}$} \\
\hline$[\%]$ VFF & 0 & 20 & 40 & 60 & 20 & 40 & 60 & 20 & 40 & 60 \\
\hline
\end{tabular}

Tab. 1.Different types of materials identification

$0.117 \mu \mathrm{m}$ and it depends only on the matrix and particle chemical composition and seems to be independent of the size of the particle.

\section{EXPERIMENT}

The experiment was performed on the Institute of Material Science and Engineering, Faculty of Mechanical Engineering, Brno University of Technology (Mollikova, 2003).

In the studied particulate composite as the matrix copolymer PP SHAC KMT 6100 was used (produce by Shell International Chemical Co. Ltd.). The density was $0.903 \mathrm{~g} . \mathrm{cm}^{-3}$ (ISO $1133 ; 2.16 \mathrm{~kg} / 230^{\circ} \mathrm{C}$ ). This material is using for injection of assorted products (i. e. tools, cars components, equipment of household).

As rigid filler was used magnesium hydroxide in two commercial available versions (see Tab. 1); company named KISUMA 5AU and MAGNIFIN H 10. In addition MAGNIFIN $\mathrm{H} 10$ was modified by $2,5 \%$ stearic acid named ASTRA.

The material marked $\mathrm{S}$ is pure polypropylene (PP). The composites F2, F4 and F6 are combination of particles KISUMA 5AU and PP. The composites S2, S4 and S6 are combination of particles MAGNIFIN H 10 and PP.

The Young's modulus of the particle is $E=72 \mathrm{GPa}$, and the value of Poisson's ratio is $v=0.29$. The material properties characterizing the composite correspond to rigid particle $\left(\mathrm{H}_{2} \mathrm{MgO}_{2}\right.$ or $\left.\mathrm{Mg}(\mathrm{OH})_{2}\right)$ filled polypropylene at room temperature was used - elasto-plastic model (i.e. experimental data, temperature $30^{\circ} \mathrm{C}$ and $50^{\circ} \mathrm{C}$, see Fig. 1).

The estimation of particles size in composite was done at Polymer Institute Brno, spol. s r.o. From this experiment was determined size of particles as $1 \mu \mathrm{m}$.

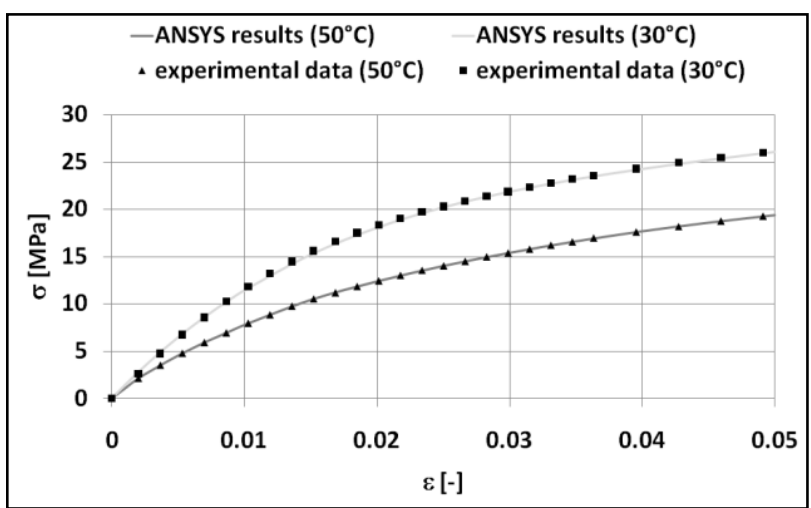

Fig. 1. The material data estimated from experiment for temperature $30^{\circ} \mathrm{C}$ and $50^{\circ} \mathrm{C}$ 


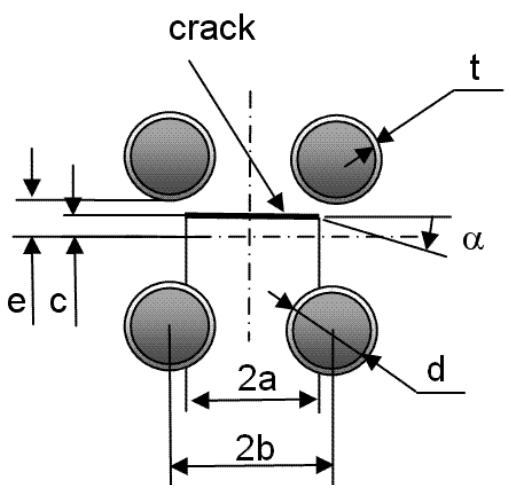

Fig. 2. Geometry of the model used for micro-crack behavior estimation in the composite

\section{NUMERICAL MODEL}

The micro-crack behavior in the three phase composite with homogenously distributed particles was numerically simulated on a microscopic scale using the finite element program ANSYS.

Only the particles placed close to the crack tip significantly influence micro-crack behavior. The representative unit cell from four particles and micro-crack is created. The geometry of this model is shown in Fig. 2.

The Young's modulus of the particles $E_{P}=72 \mathrm{GPa}$, and Poisson's ratio $v_{P}=0.29$. The corresponding parameters of the net polymer matrix (PP) are taken from the experiment. The thickness of the interphase is $0.117 \mu \mathrm{m}$, corresponding to results presented in paper (Moczó et al., 2002). The value of the Young's modulus of interphase is constant through thickness and ranges from 0.2 to $1.4 \mathrm{GPa}$ (which corresponds to facts composite without interphase).

\section{RESULTS AND DISCUSSION}

The presence of rigid particles in a polymer matrix leads to two main effects. The first one is increase of composite Young's modulus, second one is significant embrittling effect on the composite. On the fracture toughness affect several phenomena, i. e. particles shape and size, aggregation of particles or mechanical properties of the interphase. In this article the influence of interphase mechanical properties is focused. The value of interphase Young's modulus ranges from 0.2 to $1.4 \mathrm{GPa}$.

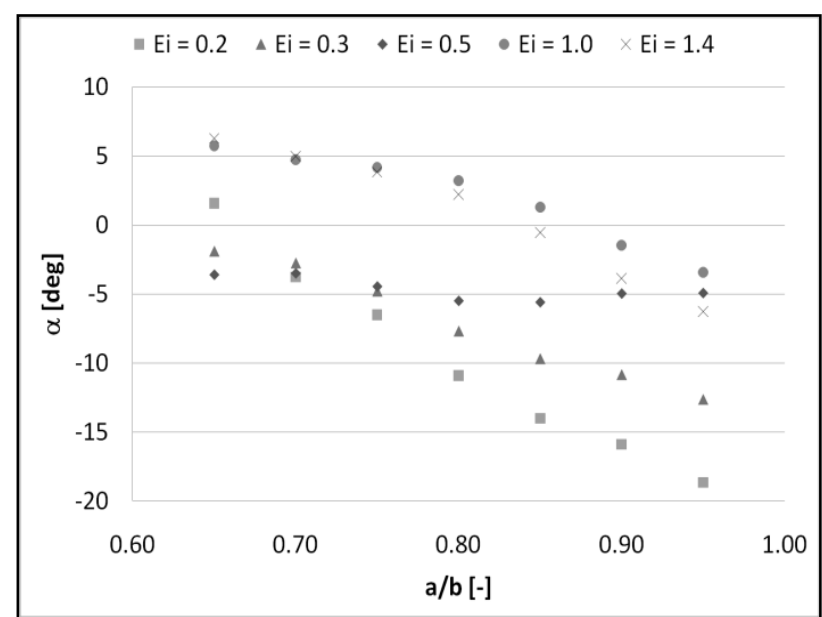

Fig. 3. Dependence of crack propagation direction $\alpha$ on the ratio $a / b$ for different values of interphase Young modulus. Computations correspond to particle size $1 \mu \mathrm{m}$ and material of matrix for temperature $30^{\circ} \mathrm{C}$.
The representative results from FEM analysis are shown in Fig. 3. It can be seen two main conclusions. For very small interphase Young's modulus $\left(E_{i}<0.3 \mathrm{GPa}\right)$ can be said that the micro-crack is attracted to particles in all considering cases. That means, the particle is covered by a softer interphase and the interphase is created a shielding effect. When the crack tip touches interphase, the interphase is damaged due to high stresses, the particle can be fully debonded and the micro-crack is blunted. The blunting of micro-cracks can contribute to increase in fracture toughness of the composite.

On other side, for higher Young's modulus values the micro-crack is deflected from particle. The crack approach to particle leads to decreasing of crack propagation direction up to change when the micro-crack is attracted by interphase in very close distance micro-crack and interphase.

\section{CONLUSIONS}

The polymeric particulate composite as three phase continuum by FEM was analyzed. The results obtained can be summarized by the following points:

- It was determined that the shielding of the rigid particles by a soft interphase can be considered one of the basic mechanisms for increasing fracture toughness.

- For smaller values of the interphase Young's modulus $\left(E_{i}<0.3 \mathrm{GPa}\right)$ was this effect stronger, for higher Young's modulus values the shielding effect was observable only for configuration micro-crack very close to interphase.

\section{ACKNOWLEDGEMENTS}

This research was supported by grant P107/10/P503 of the Czech Science Foundation.

\section{REFERENCES}

Jančář, J.; Kučera, J. \& Veselý, P. (1991). Peculiarities of mechanical response of heavily filled polypropylene composites, Journal of materials science, Vol. 26, pp. 4872-4882, ISSN: 0022-2461

Kiss, A.; Fekete, E. \& Pukanszky, B. (2007). Aggregation of $\mathrm{CaCO}_{3}$ particles in PP composites, Composites Science and Technology, Vol. 67, pp. 1574-1583, ISSN: 0266-3538

Majer, Z. (2010). The Estimation of the Young's Modulus of the Composite for Different Types of Matrix, Annals of DAAAM for 2010 \& Proceedings of the 21st International DAAAM Symposium, Zadar, Croatia, ISSN: 1726-9679, ISBN: 978-3-901509, Katalinic, B. (Ed.), pp. 1013-1014, DAAAM International,Vienna, Austria

Moczó, J.; Fekete, E. \& Pukánszky, B. (2002). Acid-base interactions and interphase formation in particulate-filled polymers, The Journal of Adhesion, Vol. 78, pp. 861-876, ISSN: $1545-5823$

Mollikova, E. (2003). Vztah mezi technologií výroby, strukturou a mechanickými vlastnostmi polypropylénu plněného hydroxidem hořečnatým, Ph.D. thesis, FSI VUT v Brně, pp. 103 (in czech)

Prod'Homme, G.; Majer, Z.; Hutar, P. \& Nahlik, L. (2008). The Effect of Particle Distribution in Polypropylene Composites on Mechanical Properties, Proceedings of 10th International Scientific Conference "APPLIED MECHANICS", ISBN 978-83-60102-49-7, Wisla, Poland

Pukánszky, B. (2005). Interfaces and interphases in multicomponent materials: past, present, future, European Polymer Journal, Vol. 41, pp. 645-662, ISSN: 0014-3057

Zuiderduin, W., C., J.; Westzaan, C.; Huétink, J. \& Gaymans, R., J. (2003). Toughening of polypropylene with calcium carbonate particles, Polymer, Vol. 44, pp. 261-275, ISSN: 0032-3861 